\title{
Impacts of climate change on the oases of the Argentinean cordillera
}

\author{
Andrea F. Carril ${ }^{1, *}$, Moira E. Doyle ${ }^{2}$, Vicente R. Barros ${ }^{2}$, Mario N. Núñez $^{1,2}$ \\ ${ }^{1}$ Centro de Investigaciones del Mar y la Atmósiera, Universidad de Buenos Aires-Consejo Nacional de Investigaciones \\ Científicas y Técnicas, Ciudad Universitaria, Pabellón II, $2^{\circ}$ piso, 1428 Buenos Aires, Argentina \\ ${ }^{2}$ Departamento de Ciencias de la Atmósiera, Facultad de Ciencias Exactas y Naturales, Ciudad Universitaria, Pabellón II, \\ $2^{\circ}$ piso, 1428 Buenos Aires, Argentina
}

\begin{abstract}
Until the mid 1970s a negative trend in the river flow values in the Argentinean provinces of San Juan and Mendoza (Cuyo region) was observed. The prevailing critical conditions and their economic and social impacts provide a basis for the characterization of an adverse climate change scenario for the region. The causes of the early 1970 s scenario were assessed in this study in order to determine whether or not it could be related to global warming conditions. River flows are dependent on winter precipitation and on accumulated snow on the Andes cordillera. The lowest negative river flow value observed can be explained by the behaviour of the Southern Oscillation Index (SOI) and other macroclimatic parameters, such as sea-surface temperatures (SSTs) of the Atlantic and Pacific oceans. It was observed that the SOI is the parameter most strongly correlated with river flows. The highest correlation was found for the 2.4- and 4.8-yr frequencies and the low 43-yr frequency. Consequently, the low river flow values observed during the early 1970 s are considered to be related to a low-frequency minimum of the El Niño-Southern Oscillation (ENSO), as well as to the behaviour of sea-surface temperature close to the coast of Chile. Both factors are associated with a minimum hemispheric temperature value. It is concluded that the $1960-70$ drought in the oases of the cordillera was not linked to a warm period. Therefore it is not appropriate, at least for the time being, to state that the oases will experience drought conditions under a global warming scenario with temperature increases of a few degrees.
\end{abstract}

KEY WORDS: Climate change - Southern Oscillation - Sea-surface temperatures - Flow anomalies . Rivers of the Cuyo region

\section{INTRODUCTION}

Until the mid 1970s a negative trend in the river flow values at the Argentinean provinces of San Juan and Mendoza (Cuyo region) was observed. Water resources in this arid Argentinean region are highly dependent on snowmelt flows. Water supply for domestic consumption, vineyard irrigation, hydroelectric power generation, and therefore industrial development would have been hindered if this trend, which fortunately reversed during the late 1970s, had continued (Fig. 1). The increase in winter precipitation over the central Andes after 1978 was associated with a weakening of the subtropical anticyclone southeastern margin, combined with a decrease in the mean

\footnotetext{
•E-mail: carril@at1.fcen.uba.ar
}

level of the Southern Oscillation Index (SOI) (Rutllant 1990).

The weakening of the subtropical anticyclone in the South Pacific is consistent with both the increased activity at the frontal zone and the excessive rainfall during the El Niño winters (Aceituno 1990). This anomalous Southern Hemisphere circulation pattern, described by Karoly (1989), produces an increase in snow accumulation on the Andes cordillera, which results in increased summer flows on both slopes. A considerable reduction in the flows of Chilean rivers located to the north of $35^{\circ} \mathrm{S}$ is observed particularly during anti-Niño events (Aceituno \& Vidal 1990).

River flows in the Cuyo region depend on winter precipitation as well as on accumulated snow on the Andes, which is in turn dependent to a large extent on the occurrence of an El Niño event. However, the neg- 


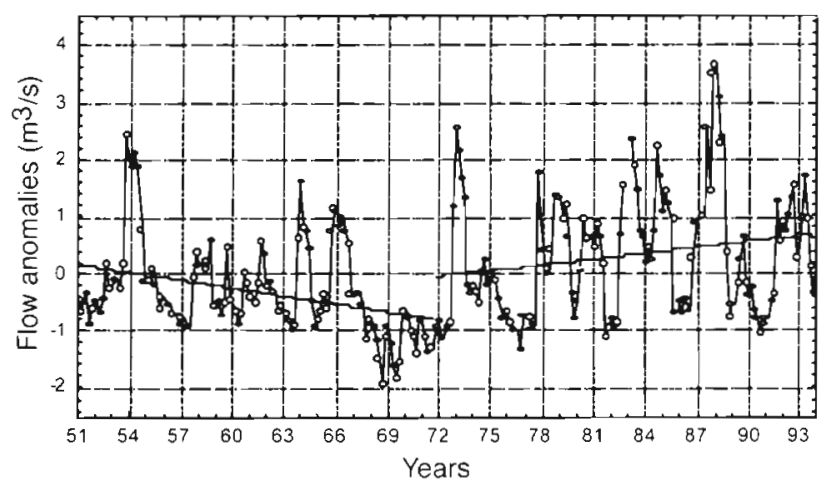

Fig. 1. Observed flow trends for Río de los Patos

ative trend observed cannot be not fully explained by a positive anomaly of the Southern Oscillation. Therefore, part of this study was oriented to identifying other macroclimatic parameters, such as sea-surface temperatures (SSTs) of the Atlantic and Pacific oceans, which could explain this behaviour.

Further, the possibility of using the relationship among SOI, SSTs and river flows as a prediction tool for flow anomalies is demonstrated, in order to facilitate water resources management.

\section{METHODOLOGY}

The data used in the study include monthly series of river flows in the Cuyo region, SOI, and SSTs of the Atlantic and Pacific oceans. Hydrologic data were provided by the firm EVARSA ('Evaluación de Recursos S.A.'). The gauging stations were selected on the basis of geographic location and length of the period covered by the available data series. Only those stations that are located closer to the mountains were considered. Among them, the ones where the flow originates only from snowmelt were selected when possible, thus eliminating the influence of convective summer pre-

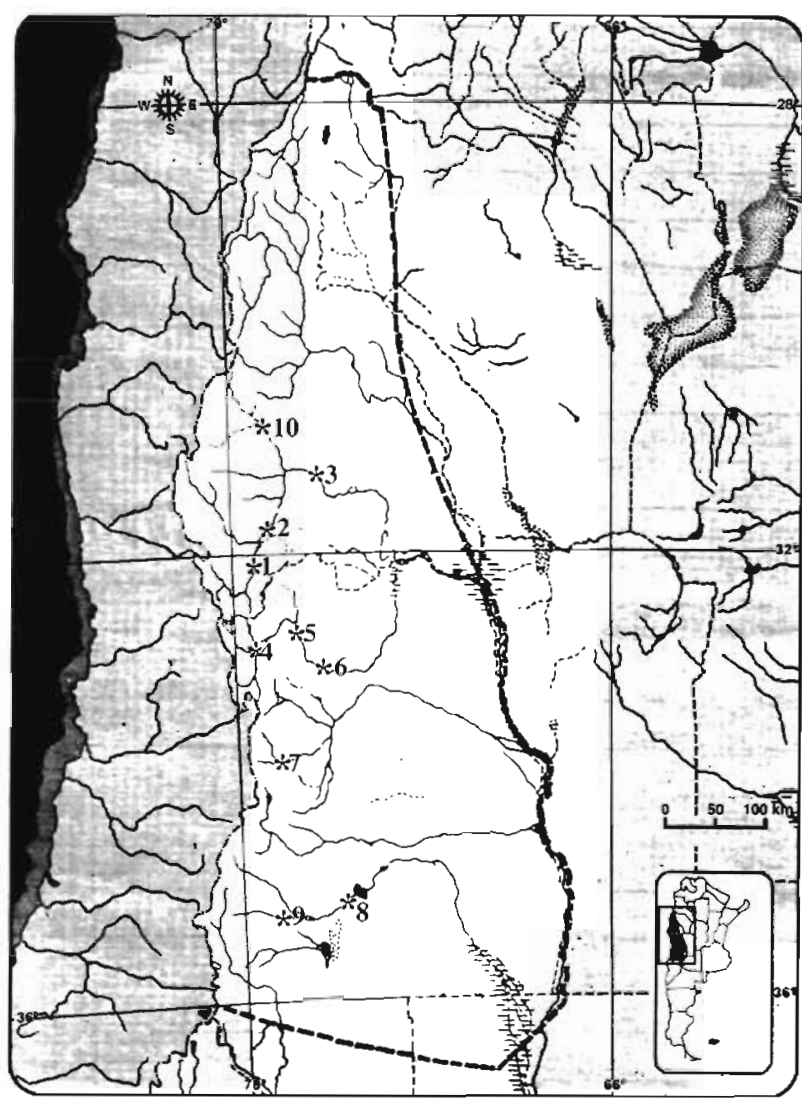

Fig. 2. Arid Andes region (part of the Cuyo region) and gauging stations used for the study: (1) Alvarez Condarco. (2) La Plateada, (3) Km. 47.3, (4) Punta de Vacas, (5) Guido, (6) Cacheuta, (7) Valle de Uco, (8) Atuel, (9) Cañada Ancha, and (10) Castaño

cipitation. The geographic location and period covered by the data for each selected station are shown in Table 1. Fig. 2 displays the study area and the selected rivers. The monthly river flow anomalies were bimonthly averaged (January-February to NovemberDecember). Due to the seasonality of the phenomenon

Table 1. Geographic location of gauging stations and data period covered

\begin{tabular}{|llllrl}
\hline River & Gauging station & Latitude & Longitude & Altitude (m) \\
\hline De los Patos & Alvarez Condarco & $31^{\circ} 57^{\prime} \mathrm{S}$ & $69^{\circ} 42^{\prime} \mathrm{W}$ & 1950 & Period \\
Castaño & Castaño & $30^{\circ} 58^{\prime} \mathrm{S}$ & $69^{\circ} 32^{\prime} \mathrm{W}$ & 1650 & $1950-1994$ \\
San Juan & Km. 47.3 & $31^{\circ} 32^{\prime} \mathrm{S}$ & $68^{\circ} 53^{\prime} \mathrm{W}$ & 945 & $1950-1988$ \\
De los Patos & La Plateada & $31^{\circ} 53^{\prime} \mathrm{S}$ & $69^{\circ} 41^{\prime} \mathrm{W}$ & 1900 & $1951-1994$ \\
Atuel & Atuel & $35^{\circ} 02^{\prime} \mathrm{S}$ & $68^{\circ} 52^{\prime} \mathrm{W}$ & 1200 & $1964-1994$ \\
Salado & Cañada Ancha & $35^{\circ} 13^{\prime} \mathrm{S}$ & $69^{\circ} 46^{\prime} \mathrm{W}$ & 1700 & $1940-1994$ \\
Mendoza & Guido & $32^{\circ} 51^{\prime} \mathrm{S}$ & $69^{\circ} 16^{\prime} \mathrm{W}$ & 1550 & $1956-1994$ \\
Mendoza & Cacheuta & $33^{\circ} 01^{\prime} \mathrm{S}$ & $69^{\circ} 07^{\prime} \mathrm{W}$ & 1238 & $1938-1990$ \\
Mendoza & Punta de Vacas & $32^{\circ} 51^{\prime} \mathrm{S}$ & $69^{\circ} 46^{\prime} \mathrm{W}$ & 2430 & $1948-1994$ \\
Tunuyán & Valle de Uco & $33^{\circ} 47^{\prime} \mathrm{S}$ & $69^{\circ} 15^{\prime} \mathrm{W}$ & 1200 & $1954-1994$ \\
\hline
\end{tabular}


which affects river flows, it was necessary to remove the high frequencies and synoptic noise by using such bimonthly standardized series.

The SOI was calculated as the standardized difference between the sea-level pressure at Tahití $\left(18^{\circ} \mathrm{S}\right.$, $\left.150^{\circ} \mathrm{W}\right)$ and Darwin $\left(12^{\circ} \mathrm{S}, 131^{\circ} \mathrm{W}\right)$ during the 1939 to 1994 period. These data were provided by the U.S. National Oceanic and Atmospheric Administration (NOAA). The bimonthly index was estimated using the procedure described for river flow anomalies. The positive phase of the SOI is defined by abnormally high/ low pressures at Tahití/Darwin.

Comprehensive Ocean Atmosphere Data Sets (COADS) provided by the U.S. National Center for Atmospheric Research (NCAR) were used. These oceanographic data are available on a $10^{\circ} \times 10^{\circ} \mathrm{grid}$ covering all oceans. The data for the Atlantic and Pacific oceans between $0^{\circ}$ and $60^{\circ} \mathrm{S}$ latitude were used in this study in 2 ways: (1) the series were processed for each box following the previously described method of bimonthly averaging, and (2) 4 regions of interest were defined -3 in the Pacific Ocean and 1 in the Atlantic Ocean-as described below.

A statistical analysis, based on correlation coefficient matrices and spectral and cross spectral analysis, was applied to the data series.

\section{RESULTS}

\subsection{Correlation analysis}

The strong relationships between the SOI, the winter precipitation in the central Andes, and the consequent summer discharge of the rivers in the Cuyo region have already been largely demonstrated. The correlation matrices between the bimonthly river flow anomalies and the SOI series were calculated with the purpose of further exploring this interaction. Results were tested to the $5 \%$ significance level. The highest corre- lation coefficients for summer flows were found for the May-June SOI, although in some cases the best results were obtained for July-August (Table 2).

According to Rutllant (1990), the increase in winter precipitation in the central Andes may be influenced by the SSTs at the Equatorial Pacific. In general, exceptionally humid/dry winters in central Chile are associated with relatively high/low SSTs in the central Pacific, although this is not always the case (Aceituno et al. 1989). To verify the above for the region leeward of the Andes, the flow anomaly series were correlated to each Pacific SST series available. Furthermore, summer precipitation can cause an increase in the flows at the stations most distant from the mountains, and this summer precipitation depends on the advection of humidity from the Atlantic Ocean; therefore, the processes associated with the Atlantic Ocean were also analyzed.

The correlation matrices between the bimonthly SST series for each grid point and the bimonthly flow anomaly series for each gauging station were calculated first. Four main regions were defined on the basis of the highest correlation coefficients at a $5 \%$ significance level: Pacific A, Pacific B, Pacific C and Atlantic (Fig. 3). The grid points from the Pacific A, Pacific $B$ and Atlantic regions have a positive correlation with flows, while the Pacific $C$ region grid points have a negative one.

A mean time series was generated for each region and later used for calculating correlations. Tables 3 to 6 display the correlation coefficients obtained for each gauging station and oceanic region studied. In general, summer flow volume is highly correlated with the JulyAugust and September-October bimonthly SST series.

Figs. 4 to 7 display the SST series for each region. A centered 5-bimonth running mean was calculated in order to remove the high frequency cycles and the possible data errors. Further, each series was adjusted using the least squares method (fifth-degree polynomial), in order to visualize the low frequency oscillation

Table 2. Highest correlation values between summer river flow anomalies (Nov-Dec, Jan-Feb, Mar-Apr) and bimonthly SOI (months for SOI are given in parentheses)

\begin{tabular}{|llccc|}
\hline & Station & Nov-Dec & Jan-Feb & Mar-Apr \\
\hline De los Patos & Alvarez Condarco & -0.62 (May-Jun) & -0.67 (May-Jun) & -0.65 (May-Jun) \\
Castaño & Castaño & -0.61 (Jul-Aug) & -0.59 (May-Jun) & -0.60 (May-Jun) \\
San Juan & Km. 47.3 & -0.63 (May-Jun) & -0.69 (May-Jun) & -0.68 (May-Jun) \\
De los Patos & La Plateada & -0.64 (May-Jun) & -0.67 (May-Jun) & -0.69 (May-Jun) \\
Atuel & Atuel & -0.56 (May-Jun) & -0.53 (Nov-Dec) & -0.51 (Nov-Dec) \\
Salado & Cañada Ancha & -0.42 (Sep-Oct) & -0.48 (Sep-Oct) & -0.41 (Jul-Aug) \\
Mendoza & Guido & -0.54 (May-Jun) & -0.55 (Jul-Aug) & -0.56 (May-Jun) \\
Mendoza & Cacheuta & -0.54 (Jul-Aug) & -0.54 (Jul-Aug) & -0.50 (Jul-Aug) \\
Mendoza & Punta de Vacas & -0.59 (Jul-Aug) & -0.62 (Jul-Aug) & -0.64 (May-Jun) \\
Tunuyán & Valle de Uco & -0.61 (May-Jun) & -0.59 (May-Jun) & -0.61 (May-Jun) \\
\hline
\end{tabular}


which modulates each one of these regions. The Pacific A region (Fig. 4) experienced a negative trend until the mid 1970 s and a subsequent recovery. The conditions in this region are positively correlated with flows, showing a similar trend as well as a minimum value coinciding with drought years in the Cuyo region. Another characteristic observed based on the analysis of the moving average series is the high intensity of the cold events during years with a negative trend, although the intensity of the warm events is similar for both periods.

The behaviour of the second region

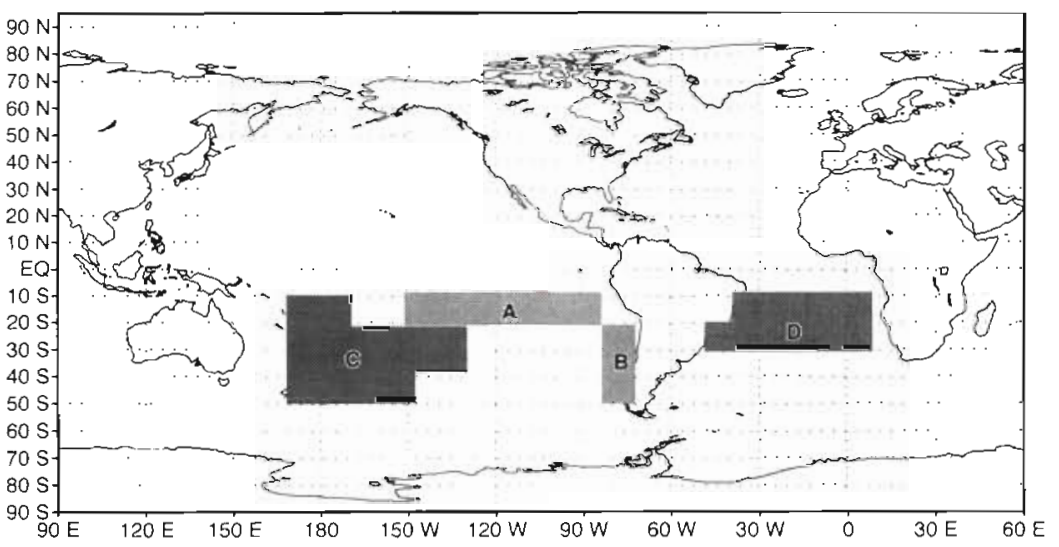

Fig. 3. Oceanic regions having an influence on river flows: $A$ : Pacific $A_{i}$ B: Pacific B; C: Pacific C; D: Atlantic analyzed, the Pacific B region (Fig. 5), is analogous to the one described above. However, the amplitude of the low-frequency oscillation is lower. Even though events in this region are also positively correlated with the behaviour of the rivers at the Cuyo region, this correlation is not as strong as in the previous case, since some of the coefficients are statistically non-significant.

Events in the western Pacific Ocean are negatively correlated to the river flows under study. As can be observed in Fig. 6, no remarkable features are found, except for a relative minimum during the early 1980 s.

The Atlantic region (Fig. 7) displays, on average, temperatures below the mean during the 1951 to 1970 period. In the remaining years the warm anomalies

Table 3. Highest correlation values between summer flow and bimonthly SST series in the Pacific A region

\begin{tabular}{|llccc|}
\hline River & Station & Nov-Dec & Jan-Feb & Mar-Apr \\
\hline De los Patos & Alvarez Condarco & 0.46 (Sep-Oct) & 0.50 (Sep-Oct) & 0.56 (Nov-Dec) \\
Castaño & Castaño & 0.46 (May-Jun) & 0.40 (Jul-Aug) & 0.45 (Nov-Dec) \\
San Juan & Km. 47.3 & 0.64 (Jul-Aug) & 0.70 (Jul-Aug) & 0.78 (Jul-Aug) \\
De los Patos & La Plateada & 0.54 (Sep-Oct) & 0.52 (Sep-Oct) & 0.60 (Sep-Oct) \\
Atuel & Atuel & 0.60 (Sep-Oct) & 0.56 (Sep-Oct) & 0.67 (Sep-Oct) \\
Salado & Cañada Ancha & 0.30 (Sep-Oct) & 0.34 (Sep-Oct) & 0.45 (Sep-Oct) \\
Mendoza & Guido & 0.60 (Sep-Oct) & 0.65 (Sep-Oct) & 0.69 (Sep-Oct) \\
Mendoza & Cacheuta & 0.53 (Sep-Oct) & 0.42 (Sep-Oct) & 0.54 (Sep-Oct) \\
Mendoza & Punta de Vacas & 0.51 (Sep-Oct) & 0.55 (Sep-Oct) & 0.58 (Sep-Oct) \\
Tunuyán & Valle de Uco & 0.57 (Sep-Oct) & 0.54 (Sep-Oct) & 0.57 (Sep-Oct) \\
\hline
\end{tabular}

Table 4. Highest correlation values between summer flow and bimonthly SST series in the Pacific B region

\begin{tabular}{|llccc}
\hline River & Station & Nov-Dec & Jan-Feb & Mar-Apr \\
\hline De los Patos & Alvarez Condarco & 0.43 (Sep-Oct) & 0.48 (Sep-Oct) & 0.49 (Sep-Oct) \\
Castaño & Castaño & 0.43 (May-Jun) & 0.37 (Sep-Oct) & 0.38 (May-Apr) \\
San Juan & Km. 47.3 & 0.64 (Sep-Oct) & 0.60 (Sep-Oct) & 0.63 (Sep-Oct) \\
De los Patos & La Plateada & 0.54 (Sep-Oct) & 0.52 (Sep-Oct) & 0.56 (Sep-Oct) \\
Atuel & Atuel & 0.52 (Sep-Oct) & 0.48 (Sep-Oct) & 0.60 (Sep-Oct) \\
Salado & Cañada Ancha & 0.21 (Sep-Oct) & 0.32 (Sep-Oct) & 0.38 (Sep-Oct) \\
Mendoza & Guido & 0.59 (Sep-Oct) & 0.59 (Sep-Oct) & 0.63 (Sep-Oct) \\
Mendoza & Cacheuta & 0.36 (Sep-Oct) & 0.33 (Sep-Oct) & 0.27 (Sep-Oct) \\
Mendoza & Punta de Vacas & -0.19 (May-Jun) & 0.32 (May-Jun) & 0.33 (May-Jun) \\
Tunuyán & Valle de Uco & 0.41 (Sep-Oct) & 0.38 (Sep-Oct) & 0.44 (Sep-Oct) \\
- Non-significant coefficients & & & \\
\hline
\end{tabular}


Table 5. Highest correlation values between summer flow and bimonthly SST series in the Pacific C region

\begin{tabular}{|llccc|}
\hline River & Station & Nov-Dec & Jan-Feb & Mar-Apr \\
\hline De los Patos & Alvarez Condarco & -0.52 (Sep-Oct) & -0.52 (Sep-Oct) & -0.51 (Sep-Oct) \\
Castaño & Castaño & -0.60 (Sep-Oct) & -0.52 (Sep-Oct) & -0.61 (Sep-Oct) \\
San Juan & Km. 47.3 & -0.60 (Jul-Aug) & -0.58 (Jul-Aug) & -0.63 (Jul-Aug) \\
De los Patos & La Plateada & -0.56 (Sep-Oct) & -0.51 (Sep-Oct) & -0.57 (Sep-Oct) \\
Atuel & Atuel & -0.67 (Jul-Aug) & -0.57 (Sep-Oct) & -0.63 (Jul-Aug) \\
Salado & Cañada Ancha & -0.14 (Sep-Oct) & -0.17 (May-Jun) & -0.17 (May-Jun) \\
Mendoza & Guido & -0.64 (Jul-Aug) & -0.60 (Jul-Aug) & -0.67 (Jul-Aug) \\
Mendoza & Cacheuta & -0.26 (Jul-Aug) & $\cdot-0.25$ (Jul-Aug) & -0.24 (Jul-Aug) \\
Mendoza & Punta de Vacas & -0.67 (Sep-Oct) & -0.61 (Sep-Oct) & -0.66 (Jul-Aug) \\
Tunuyán & Valle de Uco & -0.53 (Jul-Aug) & -0.46 (Jul-Aug) & -0.50 (Jul-Aug) \\
Non-significant coefficients & & & \\
\hline
\end{tabular}

Table 6. Highest correlation values between summer flow and bimonthly SST series in the Atlantic region

\begin{tabular}{|llccc|}
\hline River & Station & Nov-Dec & Jan-Feb & Mar-Apr \\
\hline De los Patos & Alvarez Condarco & 0.51 (Jul-Aug) & 0.61 (Jul-Aug) & 0.61 (Jul-Aug) \\
Castaño & Castaño & 0.56 (Sep-Oct) & 0.62 (Sep-Oct) & 0.60 (Sep-Oct) \\
San Juan & Km. 47.3 & 0.57 (Jul-Aug) & 0.61 (Jul-Aug) & 0.62 (Jul-Aug) \\
De los Patos & La Plateada & 0.53 (Jul-Aug) & 0.58 (Jul-Aug) & 0.56 (Sep-Oct) \\
Atuel & Atuel & 0.54 (Jul-Aug) & 0.60 (Sep-Oct) & 0.61 (Sep-Oct) \\
Salado & Cañada Ancha & -0.19 (Sep-Oct) & 0.38 (Sep-Oct) & 0.39 (Sep-Oct) \\
Mendoza & Guido & 0.55 (Jul-Aug) & 0.61 (Sep-Oct) & 0.57 (Jul-Aug) \\
Mendoza & Cacheuta & 0.45 (Sep-Oct) & 0.52 (Nov-Dec) & 0.46 (Nov-Dec) \\
Mendoza & Punta de Vacas & 0.49 (Jul-Aug) & 0.54 (Sep-Oct) & 0.58 (Jul-Aug) \\
Tunuyán & Valle de Uco & 0.65 (Jul-Aug) & 0.71 (Sep-Oct) & 0.63 (Sep-Oct) \\
- Non-significant coefficients & & & \\
\end{tabular}

occurred more frequently. The abrupt change in SSTs in this area between 1973 and 1976 is consistent with the SST minimum observed in the Pacific A and Pacific B regions. Such a cold period can lead to a shift in the Atlantic subtropical anticyclone, thus affecting water vapor transport over the continental area.

The negative trend observed during the first 25 yr of the Pacific A and Pacific B series is likely to be the determining factor for the flow decrease. The warming trend observed in the Atlantic region is not related to the observed anomalies of the early 1970 s.

\subsection{Cross spectral analysis}

Spectral techniques are effective methods for the analysis of climatic series, particularly for the identification of objective elements for climate characterization. A cross spectral analysis was carried out in order to identify the main frequencies which determine the above-mentioned correlation coefficients. Cross spectral analysis is intended to classify correlation coeffi-

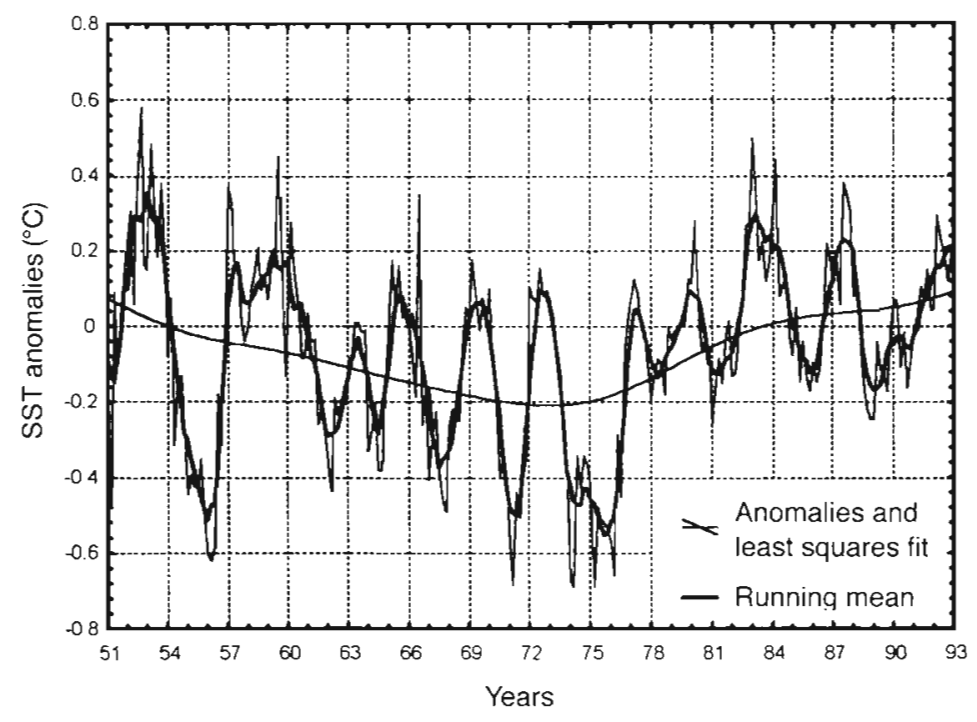

Fig. 4. Pacific A sea-surface temperature anomalies 


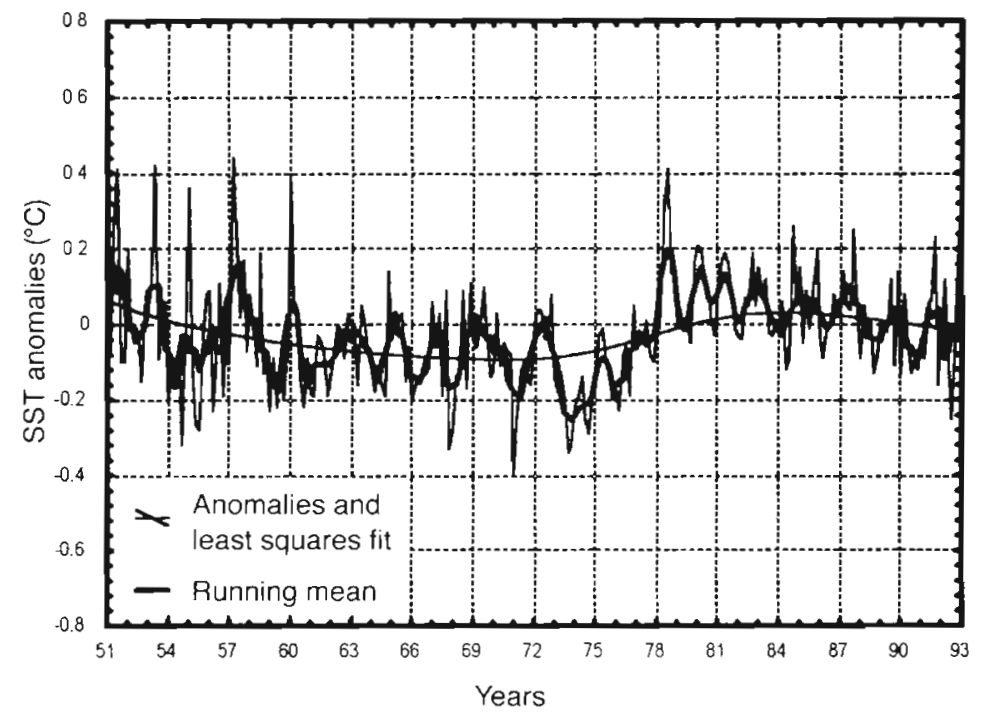

Fig. 5. Pacific B sea-surface temperature anomalies

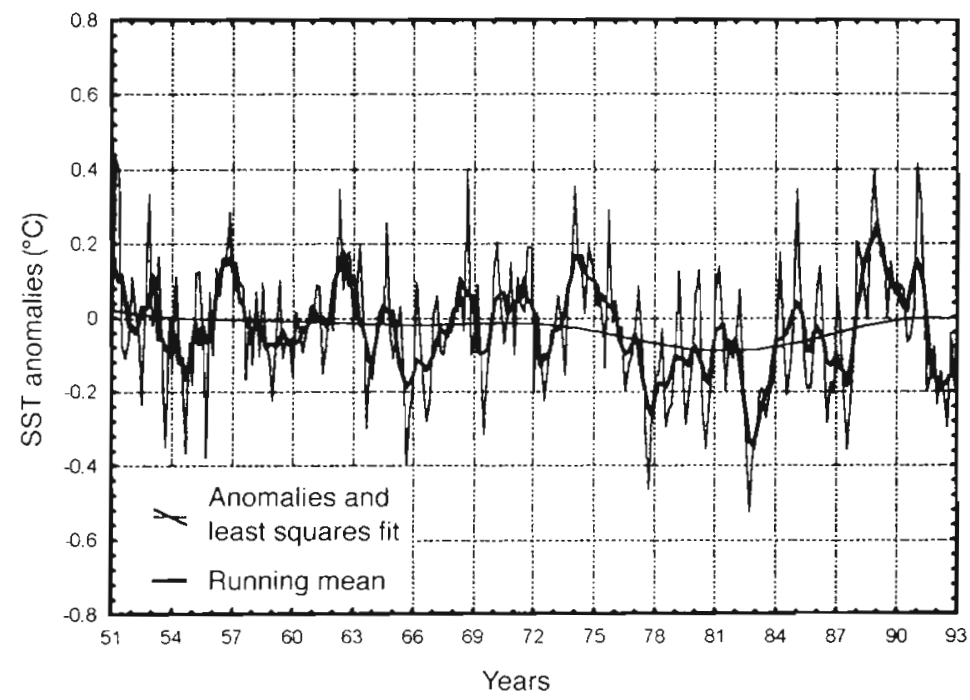

Fig. 6. Pacific $C$ sea-surface temperature anomalies

cients into 2 different frequency series. This method has been described in detail by Jenkins \& Watts (1968).

Two dominant modes of ENSO variability were identified by Rasmusson et al. (1989). One of them is a biennial mode, with periods of about 24 mo. The second one has a lower frequency and periods of 4 to $5 \mathrm{yr}$. Therefore, ENSO variability may be described in terms of the relative phase and amplitude of the 2 - and 5-yr components. The analysis of the cross spectrum between the SOI and the river flows indicates that both of the ENSO variability components are important modulators of river flows (Fig, 8). Although these results were obtained for 1 river, they may be extrapolated to the whole study area. It is thus considered that water resources in this region are strongly influenced by the occurrence of the ENSO phenomenon. A considerable percentage of the flow and SOI series variances are explained by the low-frequency waves, such as the 43-yr wave.

The squared coherency between the SOI and the Río de los Patos flows, which may be interpreted as the squared correlation coefficient between the cyclic components of 2 series for the same frequency, is displayed on Fig. 9. High values of this parameter were found for cycles at the shorter ENSO variability scale, i.e. the 2.4- and 4.8-yr scale, and for the 43-yr wave. As shown in Fig. 10, the lowest flow frequencies are in opposite phase to the SOI frequencies. The SOI influence on the lowest flow volumes observed for the rivers of the Cuyo region is thus confirmed. The quasi-biennial oscillation precedes the flow wave by approximately 8 mo. For example, the fall SOI effect is observed on summer flows. The phase shift of the 4.8-yr wave $(1.5$ yr) could not be directly explained. However, in some cases the winter flow series are significantly correlated with the SOI for phase shifts over 1 yr as observed in the analysis of the correlation matrices described above.

The 10.7- and 7.2-yr frequencies show considerable peaks in the real cross periodogram (Fig. 8). However, the low coherency values are indicative of a noisy relation between flows and the SOI.

Each regional SST series was also analyzed by means of spectral analysis techniques. The 5-yr periodicity mentioned above was also observed for the oceanic regions, except in the case of the Pacific B region (Table 7). In spite of this, a 14.3-yr wave was observed in this case, as well as for the Atlantic and Pacific $C$ regions, which could be understood as a multiple of the 5 -yr wave. The highest peaks observed on the periodogram for the Pacific A and B regions correspond to the low 43-yr frequency. The results obtained when the series were adjusted by means of the least squares method, as displayed in Figs. 4 \& 5, were thus confirmed.

This last frequency was also found in the cross spectral analysis between the Río de los Patos and the oceanic regions, with a 0.95 and 0.98 coherency respectively (Table 8). This wave was also observed, although with a lower coherency, when the influence of the Atlantic-region processes on river flows was analyzed.

Another dominant mode observed on the basis of the cross spectral analysis between the Río de los Patos 
and the Pacific A region is the one related to the ENSO phenomenon ( 4.8 yr). In the case of the Pacific $\mathrm{C}$ region high coherency values were found both for the biennial and the 4.8 yr mode.

\section{DISCUSSION}

Public interest in climate change issues mainly focusses on the potential vulnerability of productive systems and the possible adaptation measures. Thus, it is considered that the drought conditions in the oases of the Cuyo region during the 1960 to 1970 period may be used as an example of an adverse climatic scenario on which to base regional adaptation studies. However, caution should be exercised in the selection of scenarios for long-term projections of potential effects of climate change. The Cuyo region has been identified on several occasions as a region particularly vulnerable to the effects of global warming. However, as shown in this assessment, the drought that occurred in the cordillera oases was in phase with the observed SST minimum values in the Pacific $A$ and $B$ regions. The cooling in these oceanic regions is not only a regional phenomenon. It in fact corresponds to the hemispheric minimum in the subtropical region reported by Angell (1994) (Fig. 11). Therefore, it is not possible to state that an increase of a few degrees in global temperature would put water availability in the region at risk.

\section{CONCLUSIONS}

River flows in the Mendoza and San Juan provinces of the Cuyo region are highly dependent on winter precipita-

Table 7. Some SST cycles observed in the study regions

\begin{tabular}{|c|c|}
\hline & Cycles (yr) \\
\hline Pacific A & $43,4.8$ \\
\hline Pacific B & $43,14.3,21.5$ \\
\hline Pacific C & $1,14.3,5.4,4.8$ \\
\hline Atlantic & $10.8,14.3,5.4,7.2$ \\
\hline
\end{tabular}

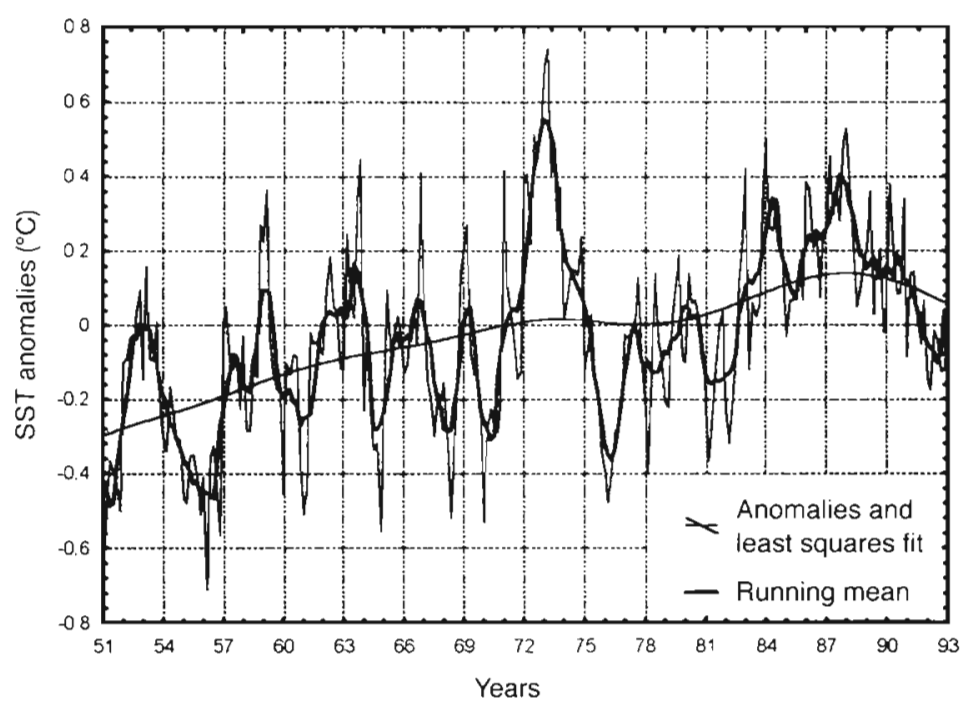

Fig. 7. Atlantic sea-surface temperature anomalies

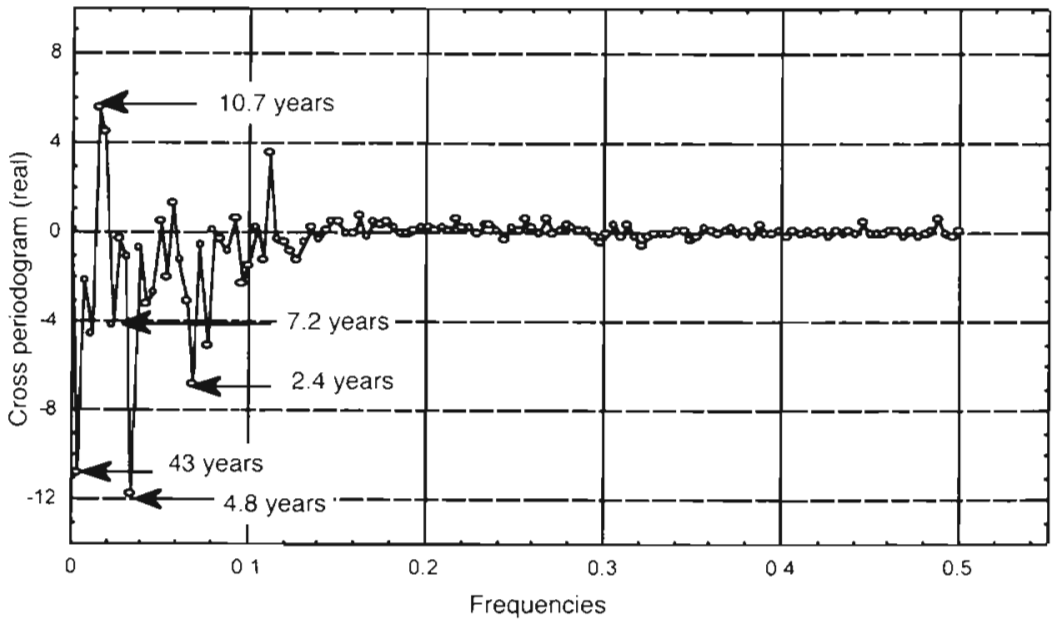

Fig. 8. Cross spectral analysis between the SOI and the Río de los Patos flows

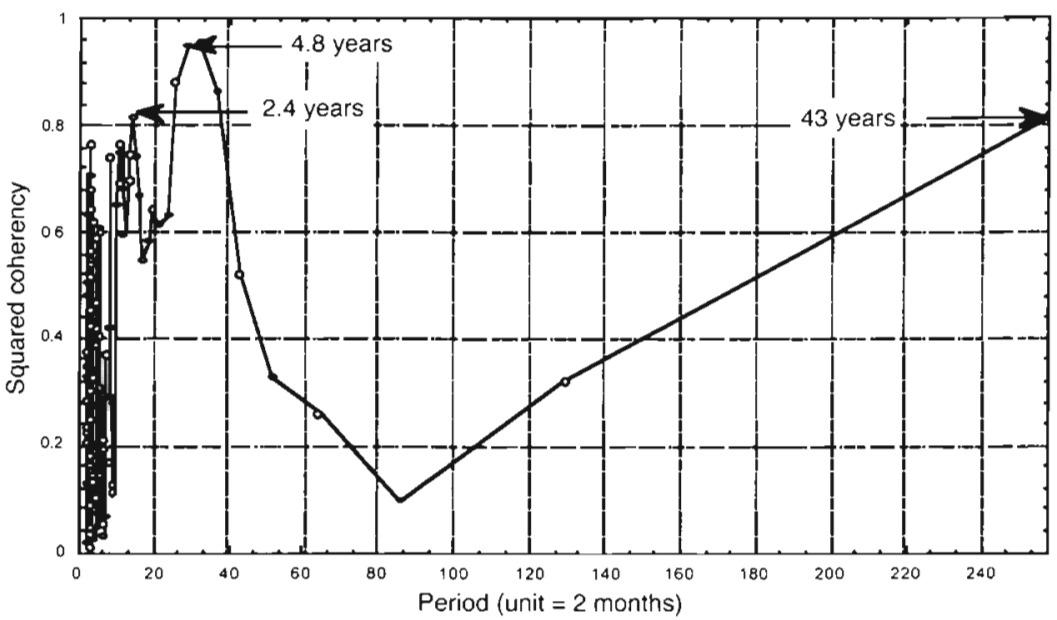

Fig. 9. Squared coherency between the SOI and the Río de los Patos flows 


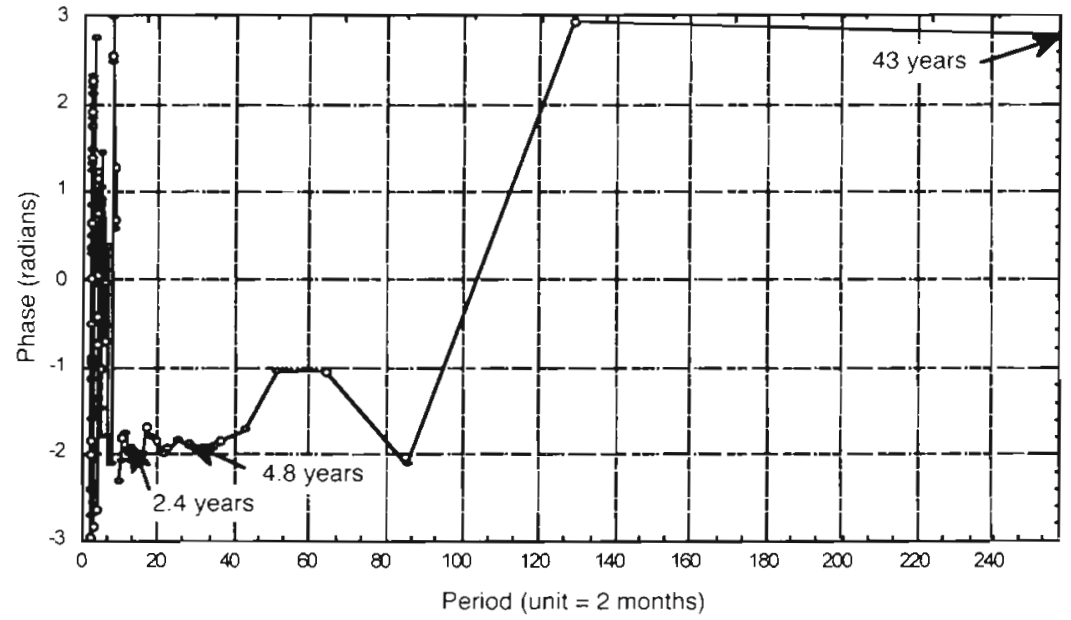

Fig. 10. Phase of the spectrum between the SOI and the Río de los Patos flows

tion regime in the mountains can be affected by any variation in the general atmospheric circulation patterns. The El Niño-Southern Oscillation is one of the phenomena related to this ocean that have significant global effects, including impacts on river flow volumes.

The drought leeward of the Andes between the 1960s and 1970s was studied using correlation and cross spectral analyses among the river flows, the SOI and the SSTs for 4 study regions: 3 in the Pacific Ocean and 1 in the Atlantic Ocean.

The coefficients with the highest significance in the correlation matrices between river flows and SOI were encountered for the relation between

tion and accumulation of snow in the Andes cordillera. The synoptic systems from the Pacific Ocean are the main precipitation-determining factor. The precipita-

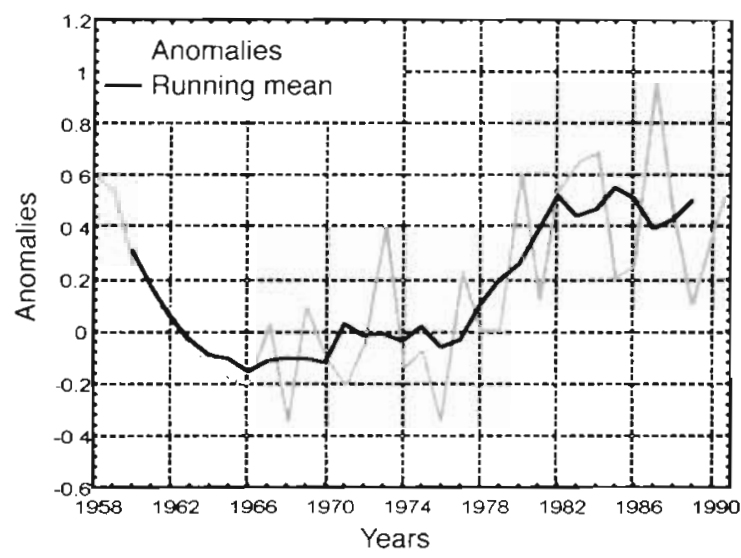

Fig. 11. Sea-surface temperature anomalies in the subtropical region

Table 8. Main peaks of the real cross periodogram between the Rio de los Patos flow and the SSTs of the different oceanic regions studied

\begin{tabular}{|cccr|}
\hline & $\begin{array}{c}\text { Frequency } \\
\text { (yr) }\end{array}$ & $\begin{array}{c}\text { Squared } \\
\text { coherency }\end{array}$ & Phase \\
\hline Atlantic & 7.2 & 0.84 & 0.20 \\
Pacific A & 43 & 0.50 & -2.45 \\
& 43 & 0.95 & -0.34 \\
Pacific B & 4.8 & 0.78 & 0.89 \\
& 43 & 0.98 & -0.17 \\
Pacific C & 21.5 & 0.81 & -0.15 \\
& 2.4 & 0.92 & -2.74 \\
& 4.8 & 0.68 & -2.43 \\
\hline
\end{tabular}

summer flows and the May-June SOI. In some cases, the relation was slightly better with the July-August winter SOI. It is thus possible to quantify the influence of equatorial Pacific events on regional climate. This relation is also confirmed on the basis of the results obtained from the analysis of SSTs. In the latter case the highest correlation between summer flow volume and SSTs was found between July and October.

The cross spectral analysis of the relation of the SOI and the equatorial Pacific SSTs to the river flows indicated that the effects of ENSO on the rivers not only apply for the 2 dominant modes of this phenomenon2.4 and $4.8 \mathrm{yr}$-but also for a long 43 -yr cycle. This low-frequency oscillation of the flows of the Cuyo region reached a minimum value in phase with the 43-yr cycle in the Pacific A and B regions, and in opposite phase with the corresponding SOI oscillation.

It is thus concluded that the negative trend observed during the first $25 \mathrm{yr}$ for the Pacific $\mathrm{A}$ and $\mathrm{B}$ series is likely to be the determining factor for the drought observed at the Cuyo region. In addition, it is believed that the warming trend of the Atlantic region series did not contribute to the occurrence of the anomalies observed in the early 1970 s.

Acknowledgements. The authors acknowledge EVARSA for providing the hydrologic data as well as Dr M. E. Castañeda for her assistance with data processing.

\section{LITERATURE CITED}

Aceituno $P(1990)$ Anomalías climáticas en la región sudamericana durante los extremos de la Oscilación Austral. Rev Geofís IGPH 32:65-78

Aceituno $P$, del Río A, Rutllant J (1989) Rainfall anomalies in the subtropical west coast of South America. Part I: Relationships with SST and convective activity over the central 
Pacific. Extended Abstracts: American Meteorological Soc (eds) Third International Conference on Southern Hemisphere Meteorology \& Oceanography, Buenos Aires, Nov $13-17,1989$, p $162-166$

Aceituno P, Vidal F (1990) Variabilidad interanual en el caudal de los ríos Andinos de Chile central en relación con la temperatura de la superficie del mar en el Pacífico central. Rev Soc Ingeniería Hidráulica (Chile) 5(1):7-19

Angell JK (1994) Global, hemispheric, and zonal temperatures anomalies derived from radiosonde records. In: Boden TA, Kaiser DP, Sepanski RJ, Stoss FW (eds) TRENDS 93: a compendium of data on global change. Carbon Dioxide Information Analysis Center Publication
No. ORNL/CDIAC-65, p 636-672

Jenkins GM, Watts DG (1968) Spectral analysis and its applications. Holden-Day Series in Time Series Analysis, Jenkins and Parzen, San Francisco

Karoly DJ (1989) Southern Hemisphere circulation features associated with the El Niño-Southern Oscillation event. J Clim 2:1239-1252

Rasmusson EM, Wang X, Ropelewski CF (1989) The biennial component of ENSO variability. Proc 21 st Int Liège Colloquium on Ocean Hydrodynamics. J Mar Sci 1:71-96

Rutllant J (1990) Cambio climático y anomalías extratropicales en la circulación atmosférica regional de América del Sur: una perspectiva ENOS. Rev Geof IGPH 32:143-150 